\title{
How to Manage Gender Bias from Within: Women in Leadership
}

\author{
Sharon Roberts \\ University Health Network \\ Donna K. Brown \\ Walden University
}

In this article, new knowledge related to managing gender bias provides a context to discuss women in leadership. This study explored how women on corporate boards coped with gender bias. Social identity theory and the role congruity theory of prejudice provided a conceptual lens of the study. Through semistructured interviews with six women on corporate boards from Canada, reflective journaling, and analysis of physical artifacts related to women revealed seven emergent themes using Yin's five phases of analysis. The findings of this study can be used by women to be more effective in managing gender bias in their leadership roles.

\section{INTRODUCTION}

Corporate boards can lose the voice and skills of women board members when the dynamics of gender bias hinder women members from being as effective as possible. In 2012, survey results from corporate boards of directors of participating public and private companies in 59 countries indicated that $87 \%$ of women reported experiencing gender-related barriers, and $56 \%$ of men disagreed with the women's perception (Groysberg \& Bell, 2013). These differences between men and women's perceptions of gender bias is an unconscious prejudice embedded in an individual's background, culture, and personal experiences with women (Cook \& Glass, 2014). Although women may have no control over men's perceptions, women can choose to control how they respond to the men's responses, and this empowers them in their leadership.

Some women's experiences with gender bias may cause them to change their perceptions of leadership in the boardroom. Leadership is the process of developing an individual's potential to attain organizational outcomes (Kouzes \& Posner, 2007). An individual who is effective as a leader continuously works and studies to improve his or her leadership skills through self-assessment (Maxwell, 2011). However, women around the world are experiencing gender bias that presents obstacles to their progress in leadership at political, social, and organizational levels (Kakabadse et al., 2015; Seierstad, Warner-Søderholm, Torchia, \& Huse, 2017).

Men's leadership support of women in reaching their full potential could eliminate gender bias toward women (LaPierre, Hill, \& Jones, 2016). There are several reasons for gender bias to continue such as the "old boy's club." The old boy's club is a climate of exclusion, unawareness of mistakes, and a lack 
of recognition of women's capabilities (Carr, Gunn, Kaplan, Raj, \& Freund, 2015). Collectively, if and when men and women (through governments, organizations, and society) collaborate, the potential of eliminating gender bias increases by changing the working climate of the old boy's club (Roberts, 2018).

While approaching gender bias is something that men and women can do, collectively, women often take the lead on this. Roberts (2018), addressed how a paradigm shift was used to consider gender bias based on women's empowerment to create positive social change within themselves rather than the traditional paradigm of changing men's gender bias toward women. Women in leadership positions who use strategies, such as mentoring, education, coaching, networking, and self-promotion are using strategies to overcome or to deal with prejudice and gender stereotypes (Kulik \& Metz, 2015; Rhode \& Packel, 2014).

In this article, the qualitative descriptive multiple case study based on the research question was as follows: How do women describe their experiences dealing with gender bias; how can gender bias influence their roles on a corporate board; how can gender bias affect their appointments that could be disruptive to board dynamics; and how can gender bias create a need to develop coping strategies to deal with gender bias as they execute their roles on a corporate board? This study increases the awareness of women's experiences in the boardroom. Included in this article, is a summary of the literature review, methodology, results, and a discussion and recommendations to facilitate continued research related to gender bias.

\section{LITERATURE REVIEW}

Gender stereotypes that limit men and women by indicating what they should do can promote gender bias in an organization that can hinder the careers and performance of women (Heilman, 2012). An indication of the bias is a board member's interactional behaviors in a group that can affect the organizational performance and leadership effectiveness to becoming disruptive to board dynamics (Buse, Bernstein, \& Bilimoria, 2016). An emerging positive language and a shift in thinking in organizations can remove direct and indirect discrimination toward women and women with families (Smith, 2014). The change needed is to achieving sex-based-equality through a social movement for the transformation of family, child-rearing arrangements, economy, wage labor market, and human consciousness that relates to gender (Law, 1984). Gender diversity must start with women to change the environment for women in general (Kulik \& Metz, 2015).

\section{Conceptual Lens}

Tajfel and Turner's (1979) social identity theory and Eagly and Karau's (2002) role congruity theory of prejudice provided the conceptual lens for this study. Tajfel and Turner (1979), pioneers of social identity scholarship, developed this theory using the concept of intergroup discrimination. Eagly and Karau (2002) created the role congruity theory of prejudice based on the dynamics of the exclusion of women from corporate boards as a result of gender bias. These connections of logical constructs create for women in leadership positions a choice to use their influence tactics based on previous experience to manage impressions of their power, status, and legitimacy that align with their character (Cheung, Lindsey, King, \& Hebl, 2016).

\section{Literature Review}

\section{Changing Gender Bias Also Means Changing Society}

Leaders can provide role model appropriate actions and attitudes to shift the social-structural forces that currently derail women from obtaining their full potential in leadership positions within an organization (Clerkin \& Ruderman, 2018). Any activity that enhances the quality of leadership within an individual or an organization is leadership in development through intentional learning, commitment, and incremental leadership experience by the individual and organization (Maxwell, 2007). Therefore, women's development as leaders is the women's responsibility (Bierema, 2016). 


\section{Societal Changes Starts With Changing Individuals}

Women who emerge as leaders are sociable, communal, and engaged in-group settings of leadership (Lemoine, Aggarwal, \& Steed, 2016). However, women's social identity can influence decision-making, social capital, cultural capital, impression management, self-monitoring, and discriminative abilities (Vinkenburg, Jansen, Dries, \& Pepermans, 2014). Women who perceived they had a deficit in these areas found impression management a useful coping strategy against gender bias (Vinkenburg et al., 2014). As an illustration, interpersonal communications or impression management can minimize biases if minority board members develop skills to shift the focus away from their differing demographics with other members in a boardroom (Zhu, Wei, \& Hillman, 2014).

\section{The Shift Away From Demographics to Ideas and Qualifications May Be the Catalyst to Social Change}

Women who develop and master coping strategies based on gender bias to influence other individuals' perceptions of them as they transition and perform leadership roles could lead to success such as the appearance of being competent (Goffman, 1959). By instigating social change, using interventions that can address organizational behaviors against bias, women can be aware of implicit gender bias and their contributions to gender discrimination (Derks, Van Laar, \& Ellemers, 2016). These women's perspectives on diversity can highlight the social injustice of minority and disadvantaged women based on age, ethnicity, and race to creating possibilities for positive social change (Holck, Muhr, \& Villesèche, 2016).

\section{METHODOLOGY}

\section{Research Design}

Data sources for this study included interviews, journaling, and analysis of physical artifacts such as government reports and databases of women on corporate boards. Methodological triangulation of all data sources of this study was to provide evidence of trustworthiness of the study design and answer the research question. Gender, leadership, and identity with gender bias connected logically to a qualitative descriptive multiple case study design and the participants of this study (see Figure 1).

\section{FIGURE 1}

\section{LOGICAL CONNECTIONS OF THIS STUDY}

Method, design, and approach of inquiry

Constructs of interest

Participants

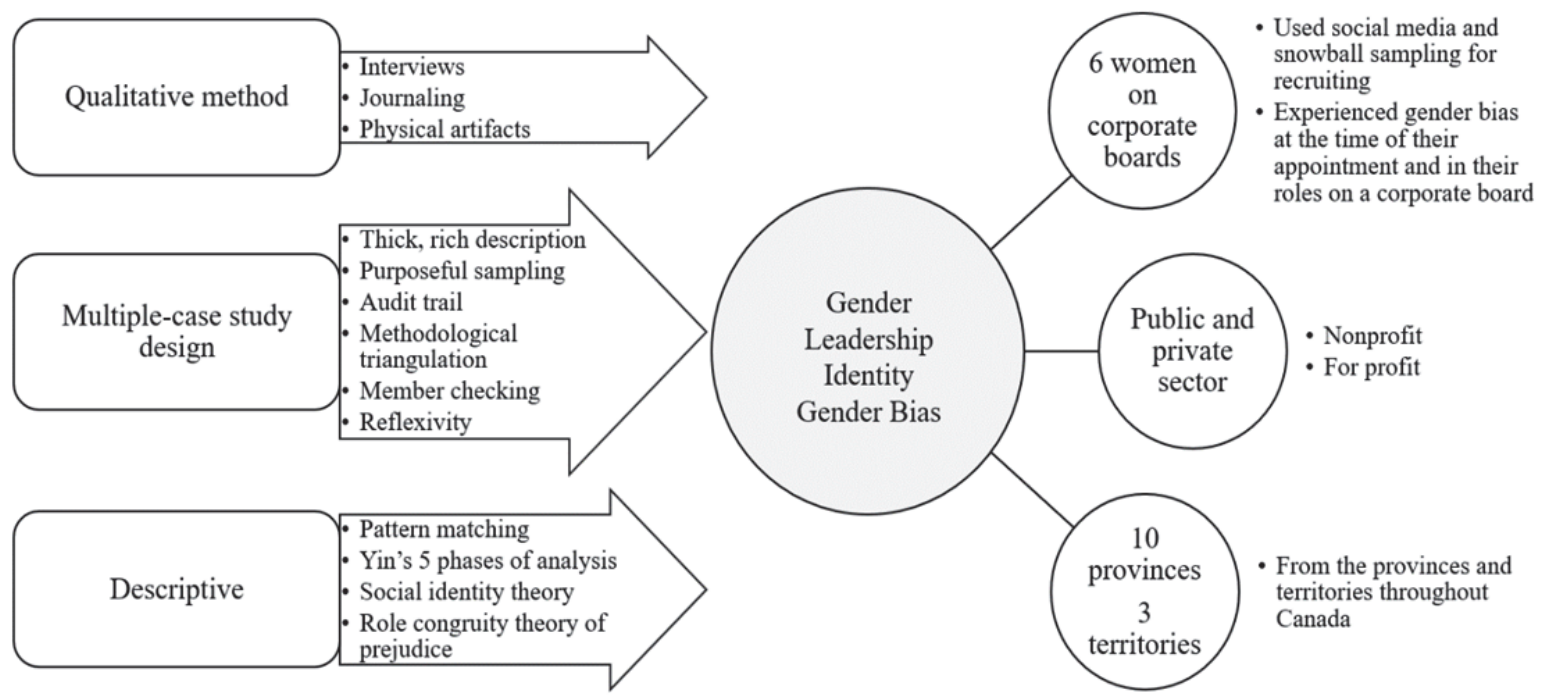




\section{Data Collection}

Social media and snowball sampling used were to recruit six English-speaking women on corporate boards who had experienced gender bias at the time of their appointment and in their roles on corporate boards in the public and private sectors in provinces and territories throughout Canada. Roberts's (2018) LinkedIn account and other similar social media sites used was to post a social media message that asked a contact to forward Roberts's (2018) e-mail address to any potential participant they knew for more information about how to participate in this study, including themselves if they met the criteria. Participants received an e-mail invitation to document consent and complete a demographic form by email or online using SurveyMonkey and a follow-up e-mail to book the semistructured interview. An interview protocol used with each participant during the data collection process was to maintain maximum data integrity. Participants had a code assigned (using the notation Participant P01, P02, P03, P04, P06, and P09) for all data collected related to that participant such as notes taken during the semistructured interview. Participants' demographics and characteristics detailed their profile (see Table $1)$.

TABLE 1

\section{PARTICIPANTS' DEMOGRAPHICS AND CHARACTERISTICS}

\begin{tabular}{|c|c|c|c|c|c|c|c|}
\hline $\begin{array}{l}\text { Participant } \\
\text { code }\end{array}$ & $\begin{array}{c}\text { Province or } \\
\text { territory }\end{array}$ & $\begin{array}{l}\text { Industry } \\
\text { sector }\end{array}$ & $\begin{array}{c}\text { Background/ } \\
\text { skills }\end{array}$ & $\begin{array}{c}\text { Organizational } \\
\text { appointment }\end{array}$ & $\begin{array}{l}\text { Board } \\
\text { years }\end{array}$ & $\begin{array}{c}\text { Board } \\
\text { seats }\end{array}$ & Role \\
\hline P01 & Alberta & Private & $\begin{array}{l}\text { Law/ municipal } \\
\text { and nonprofit } \\
\text { boards }\end{array}$ & Business as usual & 2 & 1 & $\begin{array}{l}\text { Board } \\
\text { member }\end{array}$ \\
\hline P02 & Ontario & Private & $\begin{array}{l}\text { Finance/ } \\
\text { leadership }\end{array}$ & Business as usual & 4 & 1 & CEO \\
\hline P03 & Quebec & Public & $\begin{array}{l}\text { Engineer/ } \\
\text { chemical }\end{array}$ & Financial threat & 4 & 1 & $\begin{array}{l}\text { Board } \\
\text { member }\end{array}$ \\
\hline P04 & Ontario & Public & $\begin{array}{c}\text { Entrepreneur } \\
\text { board executive/ } \\
\text { private } \\
\text { multinational }\end{array}$ & $\begin{array}{l}\text { Merger and } \\
\text { acquisition }\end{array}$ & 10 & 1 & $\begin{array}{c}\text { Committee } \\
\text { chair }\end{array}$ \\
\hline P06 & Ontario & Private & $\begin{array}{c}\text { CEO and } \\
\text { boards/ } \\
\text { corporate } \\
\text { governance and } \\
\text { leadership }\end{array}$ & Business as usual & 10 & 1 & $\begin{array}{c}\text { Committee } \\
\text { chair }\end{array}$ \\
\hline P09 & Quebec & Public & $\begin{array}{l}\text { Town council/ } \\
\text { human } \\
\text { resources }\end{array}$ & Business as usual & 5 & 4 & $\begin{array}{l}\text { Board } \\
\text { member }\end{array}$ \\
\hline
\end{tabular}

Note. Information obtained from the participants' demographic forms online.

Interviews

Interviews were conducted by telephone to maintain privacy and access to participants. A two-page synthesis of analysis that was an interpretation of the semistructured interview data sent was to participants for member checking within two days following the semistructured interview to attain the earliest confirmed responses from participants. Member checking involves a researcher having a 
continuing dialogue with participants regarding the accuracy of the interpretation and meanings of the interview data (Hays, Wood, Dahl, \& Kirk-Jenkins, 2016; Patton 2015).

\section{Journaling}

Journaling was used to attain a neutral state as the researcher. The practice of reflexivity involves the researcher keeping notes in a journal on his or her emotions and beliefs about the data to avoid bias (Guba $\&$ Lincoln, 1983). A qualitative analysis of journal contents explores the interpretation of the central phenomenon causing the reduction of content to transform into essential elements which refined further into themes (Mayes, Dollarhide, Marshall, \& Rae, 2016).

\section{Physical Artifacts}

The physical artifacts are publicly available online. One such artifact was a Commonwealth Secretariat study on gender differences in leadership and business using the science of decision-making (Patel \& Buiting, 2013). Reports on women in Canada from Status of Women Canada (2016) and Statistics Canada (2016) are available to the public as physical artifacts for analysis. Included in this study were consulting reports such as Time for Change: Recruiting for Europe's Boardrooms (EY, 2013) and Women in the Boardroom: A Global Perspective (Deloitte, 2015).

\section{Data Analysis}

Yin's (2011) five phases of analysis provided a framework for data analysis that involved compiling, disassembling, reassembling, interpreting, and concluding to analyze the data. In this study, Roberts (2018) coded and analyzed the data manually before creating a model in NVivo for efficiency. Saldana's (2012) First Cycle method used was for the initial coding of data and based on themes from all data sources. The meaning of recurring concepts in the data sources questioned, such as discrimination and identity, was to ensure the themes were complete, fair, empirically accurate, credible, and value added.

\section{RESULTS}

The seven emergent themes from all data sources were discrimination, harassment, organizational climate, well-being, disruption, empowerment, and leading.

\section{Discrimination}

Most women on corporate boards experience discrimination. Gender-based discrimination is an overt action taken against a woman by a man or a woman (Bruce, Battista, Plankey, Johnson, \& Marshall, 2015). In this study, the discrimination theme occurred in $75 \%$ of data sources. There were six minor themes of discrimination which included age, being a woman, gender imbalance, stereotyping, lack of equity, and a lone female in the boardroom. Minor themes occurrence in the data ranged from $50 \%$ to $75 \%$.

\section{Harassment}

In addition, most women on corporate boards experience harassment. Harassment is any negative interpersonal interaction individuals use to create an intimidating, hostile, or offensive working environment (Neall \& Tuckey, 2014). In this study, the harassment theme occurred in $63 \%$ of data sources. The two minor themes of harassment included bullying and violence. Minor themes occurrence in the data were $63 \%$.

\section{Organizational Culture}

Women on corporate boards experience gender bias embedded within an organization. Organizational climate emerges from social information processes, and the meaning individuals within an organization attach to policies, practices, and procedures they experience (Schneider, Ehrhart, \& Macey, 2013). Organizational climate also entails the behaviors employees observe that leadership rewards, supports, 
and expects (Schneider, Ehrhart, \& Macey, 2013). In this study, the organizational climate theme occurred in $88 \%$ of data sources. There were four minor themes of organizational climate which included the old boy's club, special interest groups, diversity, and identity. Minor themes occurrence in the data ranged from $63 \%$ to $88 \%$.

\section{Well-Being}

Although most women on corporate boards ignore gender bias, it may take a toll on their well-being. An individual's well-being provides a sense of self, embedded in a wider system of recognition, and misrecognition of capabilities, social integration, security, and processes to benefit an individual (Atkinson, 2013). In this study, the well-being theme occurred in $63 \%$ of data sources. There were three minor themes of well-being which included stress, family conflict, and expectations of society. Minor themes occurrence in the data ranged from $50 \%$ to $63 \%$.

\section{Disruption}

Most women on corporate boards experience disturbance with unfamiliar and dissimilar behaviors of board members. Disruption can destabilize an individual characterized by confusion, deliberate threats, external pressures, and resource limits (Fiksel, Polyviou, Croxton, \& Pettit, 2015). In this study, the disruption theme occurred in $88 \%$ of data sources. The four minor themes of disruption included role challenge, leaving, targeted, and exclusion from decision-making. Minor themes occurrence in the data ranged from $50 \%$ to $75 \%$.

\section{Empowerment}

Women on corporate boards experience a power shift. Empowerment is a meaningful shift in the experience of power attained through an individual's interactions in the social world that build confidence, connections, and consciousness of authenticity in an individual (Cattaneo \& Goodman, 2015). In this study, the empowerment theme occurred in $100 \%$ of data sources. There were seven minor themes of empowerment which included efficacy, entrepreneurship, skill building, knowledge building, a mentor relationship, networking, and relationship building. Minor themes occurrence in the data ranged from $75 \%$ to $100 \%$.

\section{Leading}

Women on corporate boards experience an elevated status in leadership. An individual can attain a state of self-actualization to adopt a virtuous behavior based on a journey toward an ideal self that takes courage to choose who an individual is to become and to work in excellence to attain humanness (Fernando \& Chowdhury, 2016). In this study, the leading theme occurred in $100 \%$ of data sources. There were seven minor themes of leading included having a purposeful goal, support system, and inclusion, advocacy for change, CEO experience, impression management, and governance. Minor themes occurrence in the data ranged from $50 \%$ to $100 \%$. Table 2 depicts examples of methodological triangulation of all data sources by major themes. 
TABLE 2

EXAMPLES OF METHODOLOGICAL TRIANGULATION OF ALL DATA SOURCES

\begin{tabular}{|c|c|c|c|}
\hline Major themes & Semistructured interviews & Journal notes & Analysis of physical artifacts \\
\hline Discrimination & $\begin{array}{l}\text { "Assumptions about me and } \\
\text { my appearance, which was } \\
\text { different from the majority of } \\
\text { the board members of older } \\
\text { homophobic White men, I } \\
\text { became an object of } \\
\text { stereotyping to a race, } \\
\text { religion, and its practices of } \\
\text { which I had no associations." } \\
\text { (Participant P01) }\end{array}$ & $\begin{array}{l}\text { Things we may ignore } \\
\text { that can make a } \\
\text { difference to an } \\
\text { individual's success } \\
\text { was consciously } \\
\text { intimidating to her } \\
\text { daily (journal notes). }\end{array}$ & $\begin{array}{l}\text { In contrast to men, women } \\
\text { excluded in decision-making } \\
\text { process occupied inferior } \\
\text { positions to initiate } \\
\text { transformative change in } \\
\text { organizations (Jahan, 2016). }\end{array}$ \\
\hline Harassment & $\begin{array}{l}\text { "I think if I was a man, I am } \\
\text { not sure the board member } \\
\text { would have been so } \\
\text { aggressive with me the way } \\
\text { he did." (Participant P03) }\end{array}$ & $\begin{array}{l}\text { Although Participant } \\
\text { P03 is dismissing the } \\
\text { intimidating, hostile, } \\
\text { and aggression by the } \\
\text { board member toward } \\
\text { her, this may be an } \\
\text { unpleasant experience } \\
\text { for her (journal notes). }\end{array}$ & $\begin{array}{l}\text { Women expected that it is } \\
\text { "normal" to experience } \\
\text { harassment from men. } \\
\text { Harassment is a barrier } \\
\text { against women that include } \\
\text { bullying (United Nations } \\
\text { Development Programme, } \\
\text { 2016). }\end{array}$ \\
\hline $\begin{array}{l}\text { Organizational } \\
\text { climate }\end{array}$ & $\begin{array}{l}\text { "Male board members are } \\
\text { not open to the opinions of } \\
\text { others, drifted, or not } \\
\text { engaged." (Participant P04) }\end{array}$ & $\begin{array}{l}\text { Old boy's club } \\
\text { (journal notes). }\end{array}$ & $\begin{array}{l}\text { An organization's climate } \\
\text { could have unstated } \\
\text { assumptions about women } \\
\text { and their commitment to } \\
\text { advancement because of } \\
\text { family conflict (EY, 2011). }\end{array}$ \\
\hline Well-being & $\begin{array}{l}\text { "I just push forward through } \\
\text { gender bias." (Participant } \\
\text { P06) }\end{array}$ & $\begin{array}{l}\text { Funny how this } \\
\text { interview is so } \\
\text { calming but the } \\
\text { strength and focus of } \\
\text { Participant P06 are } \\
\text { evident (journal } \\
\text { notes). }\end{array}$ & $\begin{array}{l}\text { Women seeking leadership } \\
\text { positions must balance work } \\
\text { and family responsibilities } \\
\text { (Hill, Miller, Benson, \& } \\
\text { Handley, 2016). }\end{array}$ \\
\hline Disruption & $\begin{array}{l}\text { "A gender imbalance board } \\
\text { can have different dynamics } \\
\text { versus a balanced board of } \\
\text { more bias where women may } \\
\text { feel the need to strut or show } \\
\text { their stuff." (Participant P02) }\end{array}$ & $\begin{array}{l}\text { I hear in her voice her } \\
\text { confidence and trust of } \\
\text { her board members } \\
\text { (journal notes). }\end{array}$ & $\begin{array}{l}\text { In a report from EY related to } \\
\text { recruiting practices of } \\
\text { European boards findings } \\
\text { indicated that boardroom } \\
\text { appointments remain closed } \\
\text { to candidates with previous } \\
\text { experience and personal } \\
\text { networks (EY, 2013). }\end{array}$ \\
\hline Empowerment & $\begin{array}{l}\text { "If observed I try to bring it } \\
\text { into the light at a board } \\
\text { meeting to realize that some } \\
\text { of the decision-making } \\
\text { occurred outside of the } \\
\text { boardroom." (Participant } \\
\text { P09) }\end{array}$ & $\begin{array}{l}\text { This information is so } \\
\text { rich and fun (journal } \\
\text { notes). }\end{array}$ & $\begin{array}{l}\text { Gender-based inequality } \\
\text { diminishes with increased } \\
\text { levels of education (Statistics } \\
\text { Canada, 2016). }\end{array}$ \\
\hline
\end{tabular}




\begin{tabular}{llll}
\hline Major themes & \multicolumn{1}{c}{ Semistructured interviews } & \multicolumn{1}{c}{ Journal notes } & Analysis of physical artifacts \\
\hline Leading & "As a board leader, my role & Her advice to women & Gender differences exist in \\
is to help with the why, own & shows the depth of her & the perception of risk, and \\
it, be responsible, and show & journey and learning & with the perceived value it \\
up." (Participant P04) & $\begin{array}{l}\text { to cope with gender } \\
\text { bias by leading }\end{array}$ & $\begin{array}{l}\text { formed the basis of actions } \\
\text { and decisions of leaders (Patel }\end{array}$ \\
& & (journal notes). & \& Buiting, 2013). \\
\hline
\end{tabular}

\section{Interpretation of Findings}

The women in leadership positions described their experiences based on men's behaviors of discrimination and harassment toward them. An organizational climate embedded with gender bias affected these women's well-being, which influenced women's roles on corporate boards. Their appointments negatively disrupted board dynamics. However, these women were successful by using their empowerment to create behavioral change within themselves. In addition to leading organizations, they thwarted the bias they encountered while executing their roles on a corporate board.

\section{Some Responses of Participants}

\section{Discrimination}

The treatment by a board chair experienced by Participant P04 debased her, and she stated,

I was the first woman in a senior role in an organization. Individuals' that I encountered did not expect women as leaders and providers. I continued to work during my pregnancy because of my beliefs. I returned to work sooner than expected because peers undermined my efforts while I was on maternity leave and had to rearrange my family's lives. I was reminded by peers that I was with family and need not be at work. [...] My experience of gender bias of being devalued, degraded and humiliated was because I am a woman.

\section{Harassment}

Participant P01 discovered, "Violence, yelling, and accusations of sexual harassment towards the few women on the board and in the firm were normal." Some women become targets for harassment by men who view women as a threat to their social status (Berdahl, 2007).

\section{Well-Being}

P01's replied,

Told me that I was not a good fit, I experienced overwhelming stress from peers who isolated and undermined me. I became disheartened about the behaviors I experienced from them. It was too stressful and uncomfortable to continue in that climate and to raise a young family. I became angry because of the social injustice towards me.

Participant P03 responded,

I had many discomforts and a lot of conflict during this time when I started. I faced reality, and because I am a structured person, I had to know all my projects and files in depth so that they can see I was in control and knew what I was talking.

\section{Organizational Climate}

Most participants had experience with the old boy's club as Participant P06 indicated,

Gender bias is a traditional attraction to comfort. Most boards are comfortable with their old boy's club, especially on the larger corporate boards. Women have not occupied the highest level of major corporations, so the pool of individuals that boards attract are 
individuals with experience such as a CEO of a bank, insurance company, large investment house, or in real estate. These individuals have had the advantage of who they know, and their friends are male.

\section{Disruption}

The women's appointments can disrupt board dynamics. Participant P06 advised,

I have witnessed younger women less experienced with a change the world attitude overextending their influence that tends to get them into difficulties on a corporate board. I share an observation that when a personal bias to something exists it will become an issue. At the board level, the intent is to solve and not create problems. Governance is different from operational understanding requiring unique skills set as a director rather than a specialist. Gender bias is present in the workplace. It will take time for bias to work its way through the system. Men and women perceive things differently, but that difference in perception is a desired trait for a boardroom. Differences of opinion rather than being afraid if it is okay should not matter because of gender, race, or color.

\section{Empowerment}

The women felt obligated to represent all women in the boardroom. Participant P01 indicated,

I no longer have a dependency on anyone for support, acknowledgment, or expectation to understand who I am, and my cause. None of these things matter anymore to me. My advice to women is to be cautious about joining corporate boards. Seek boards that prove they are inclusive of women, visible minorities, and all orientations in general. The board is against violence, reserve seats for women, and reflects your values.

\section{Participant P02 noted,}

My advice to women is to make sure those facets of your life are moving forward simultaneously. One outracing the other will get you out of balance. An imbalance is never going to help you to contribute especially if you are on a corporate board and if you are in a place of leadership. Women should not be afraid to ask questions, participate, speak up, ask for assistance, for opportunities, make yourself known, and stand out front. If you can bring all those facets, it can add to what you are doing in the workplace.

Control of emotions is aware of self as an individual. Participant P03 stated,

In my previous experience and staying calm in those situations, you need to stay strong and focused on what you are supposed to do even though it happens. You need to maintain the focus and control the meeting and not be distracted or out of control when it happens. These are the key things you do when an event happens, and then after the meeting, you try to find the solution if it is possible.

\section{Participant P04 replied,}

Taking control of the environment is a choice, and it creates the environment for the best discussions to happen or the risk of not doing. I never put myself in a position of not showing up completely prepared and know what I can do to help other individuals. I know and own the knowledge of why I am here, the board, and individual. [...] It is important for women to present a very professional image. 
Leading

Confidence is key to appearances as a leader and a woman. Participant P06 responded,

Be passionate about the idea of governance to be an effective director with a capacity to understand and make an organization better such as in fundraising or advice on strategy. The objective is to serve and not work for the company. Ask questions without the preamble. Develop emotional skills that are mature and balanced. Be open to diverse opinions, network, and connect with individuals.

Participant P09 reported,

"Women should not be afraid and ask questions is a way to indicate that you are interested and able to make the right decisions." In addition to leading organizations, the women thwarted the bias they encountered while executing their roles on a corporate board. A sense of fulfillment in thwarting gender bias shared among the participants provide hope for other women in leadership positions. Participant P01 stated, "I am at peace now with the freedom to influence change." Supported by Participant P03 noted, "There is work still to do, but we are going in the right direction."

Participant P02 indicated,

I am an advocate for working women of the middle class to find their voices and provide needed support in this niche area. I focus on a well-defined mission to understand what I do and why for other individuals to follow my lead. I voice my ideas and opinions with ease and have a clear sense of purpose.

Participant P04 responded,

Show your children what you do. It is the most valuable gift you can give for themselves. How you prepare, how you think through problems, and how you present yourself. These are the gifts for the next generation who may not know what gender bias is. I look at it as an opportunity for a greater purpose. I decided that when you start having self-doubt, it can keep you from acting, and nothing hurts your business or career more than not acting. Women should not lose their humanness.

Participant P06 said,

Women seeking to join boards is to be passionate about the idea of governance to be an effective director with a capacity to understand and make an organization better such as in fundraising or advice on strategy. The objective is to serve and not work for the company. Ask questions without the preamble. Develop emotional skills that are mature and balanced. Be open to diverse opinions, network, and connect with individuals. A calmer more balanced approach is more attractive which provides a better opportunity to join a board that will teach you rather than a push and pulls approach that will not work. It is push-pull where you need to be able to join a board that gives back as well as you give. If it is a one-way street, it does not work for either side. A CEO of an organization does not want a board they have to fight with, that the board is better than him or her, or second-guessing the decision-making. 
Participant P09 replied,

Board work includes many meetings. Many meetings without the support and a demanding job are not easy to do until after retiring it is much easier to take up board positions. It is easier to start on boards when young but important to have a good support system as a woman. I encourage women who are thinking about joining a board not to hesitate. Encourage men to say women should come on boards, for women to hear it, know that it is there, and able to do it.

\section{DISCUSSION AND RECOMMENDATIONS}

In a meta-analysis of literature related to gender bias, Mensi-Klarbach (2014) found a multilayered framework to explain why diversity was not working and why gender diversity was subject to gender bias of leadership in organizations from an individual characteristic, top management teams, organizations, and society. This study intended was to add to the body of knowledge related to gender bias and to create a new standard in research of women on corporate boards. This study is unique because of the data sources, but the study design may be transferable if a researcher chooses.

\section{Limitations of the Study}

The methodology and design of this study were beyond the researcher's control and could have affected the study results. In 109 days of data collection, Roberts (2018) sent 1,116 messages on social media to contacts across Canada. The informed consent and completed demographic forms received were online from six participants. The issue was that five of six participants confirmed their synthesis report for member checking was accurate and addressed in the report. One participant in this study did not respond to Roberts's (2018) e-mail to confirm the accuracy of the synthesis report. The limitations of member checking data in this study included a time delay because of a waiting period of 14 days for a participant to confirm by e-mail response that the synthesis report was accurate. However, the participant's responses included were in the data collected related to this study.

Intentionally, an interview protocol used was for the semistructured interviews to standardize the data collection process. The synthesis reports for member checking, coding structure, and memos on the progress of research provided an auditable examination of this study. An audit trail used was of logged events such as the NVivo date and time stamps of uploaded data sources.

The second limitation of this study focused on the unique data sources used in the study that included interviews, journaling, and analysis of physical artifacts such as government reports and databases of women on corporate boards for methodological triangulation to answer the research question. Thick, rich description and purposeful sampling used so that a future researcher will be able to decide the transferability of the study results. The findings of this study are unique and restricted to the data sources used in the study.

The third limitation of this study focused on researcher bias that could have influenced the study findings. The issue of researcher bias addressed by Roberts (2018) was through reflective journaling to attain a neutral state as the researcher. The reflexivity technique helped to suspend judgment, contain preconceptions about gender bias, and prior knowledge of this study.

\section{Recommendations for Future Research}

The findings of this study identified nine possible areas for further research that include women who use discrimination as an incentive to become more effective in leadership styles to change men's and society's attitudes on gender bias. The inclusion of women in the boardroom is a threat to the social status of men in leadership positions. Additional research needed is of the harassment, bullying, and violence toward women with a focus on legislation and directives that further reinforce male dominance in the boardroom and early experiences of gender roles preserved by society. More research is needed on the 
effort women on a corporate board exert to maintain the management and control as a board chair because of special interest groups' role in the boardroom.

Additionally, women who develop an impostor phenomenon that could allow them to evaluate themselves negatively could be a future area of research. The impostor phenomenon is a dynamic in which some women who are high achievers could experience difficulty personalizing their success because of the influence of work and family conflict (Crawford, Shanine, Whitman, \& Kacmar, 2016). Therefore, a common platform of like-minded and skilled individuals to help advance women in leadership positions could reduce any disruption to board dynamics. Further, a mentor relationship between men and women with women in leadership positions could help close the gap to facilitate women's development in leadership roles and a study for what could be the mentor relationship. Exploration needed is of the relational opportunities, and challenges women in leadership positions encounter that influence the women's careers, and decision-making in gender differences which could have different outcomes because of gender.

\section{Strategies to Cope With Gender Bias Checklist}

The empowerment techniques include self-efficacy, entrepreneurship, skill building, knowledge building, a mentor relationship, networking, and relationship building. The leading techniques include a purposeful goal, support system, and inclusion, advocacy for change, CEO experience, impression management, and governance. A positive social change could occur from the use of the strategies to cope with gender bias checklist to reduce women's experiences with a bias that influenced their role on a corporate board and disrupted board dynamics. Roberts (2018) developed the checklist from the behaviors and actions by the women to improve themselves to be effective in their roles on a corporate board. Roberts (2018) included in the checklist space to capture a date completed for each action plan to acquire a behavior to record attaining each accomplishment (see Table 3).

TABLE 3

STRATEGIES TO COPE WITH GENDER BIAS CHECKLIST

\begin{tabular}{|c|c|c|c|}
\hline Themes & Behaviors & Action plan & Date completed \\
\hline \multirow{7}{*}{ Empowerment } & Efficacy & Learn to take control of emotions & \\
\hline & Entrepreneurship & Own a business & \\
\hline & Skill building & Take a course of any gaps in skill & \\
\hline & Knowledge building & Acquire knowledge about a board & \\
\hline & Mentor relationship & Find a trusted mentor & \\
\hline & Networking & Be visible in the industry & \\
\hline & Relationship building & Create trusted relationships & \\
\hline \multirow[t]{7}{*}{ Leading } & Purposeful goal & Define what you do and why & \\
\hline & Support system & Tell family and friends & \\
\hline & Inclusion & Realize the value of different thinking & \\
\hline & Advocacy for change & Take control of the environment & \\
\hline & CEO experience & Shadow a CEO for 6 months & \\
\hline & Impression management & Have a professional image & \\
\hline & Governance & Become an effective director & \\
\hline
\end{tabular}

\section{Significance of This Study}

This study increases the awareness of women's experience in the boardroom. No longer are theoretical perspectives on women's experience in the boardroom missing from the body of knowledge related to gender bias. The findings of this study have the potential to affect positive social change at individual, organizational, and societal levels. The study results could provide information to explore 
areas for future research, and a researcher could decide whether to make the results transferable to a study.

The immediate course of action for women to address society's and men's views about women in leadership positions involves the applications of ways in which such women can cope with gender bias and still be effective in their roles on corporate boards. The empowerment of women to create behavioral change in organizations and society in relation to gender bias against women in leadership positions could help other women to advance in the boardroom and leadership positions. In this study, the women instinctively were innovative and creative in advancing themselves to returning to corporate boards in organizations that aligned to their values. By developing a plan of action to develop empowerment and leading behaviors such as indicated on the strategies to cope with gender bias checklist, women in a leadership position could work towards their goals of self-improvement preferably within one year.

\section{Positive Social Change}

The women used the empowerment and leading techniques to become successful coping with gender bias on a corporate board. The positive social change could occur from use of the strategies to cope with gender bias checklist to reduce women's experiences with a bias that influenced their roles on a corporate board and disrupted board dynamics. A standard approach to affect change in the boardroom using a common platform of like-minded and skilled individuals could help advance women in leadership positions.

The potential for positive social change at the organizational level is dependent on the actions of organizational leaders to develop and implement interventions to reduce the effects of gender bias toward women. Society could be supportive of women who speak up against harassment, are seen as a threat by men, and experience increased harassment. The positive social change could occur at the societal level by reducing the effects of gender bias toward women starting in the home, with families, parents, and children.

Too often the public schools instill gender bias in terms of how they conduct their classrooms and activities (McGee Bailey, 1993). Women will need to learn how to cope with gender bias to be successful in leadership positions with their families leading the effort. A long-term goal of diminishing gender bias could begin in preschool and early elementary school in terms of how children are taught to interact with one another downplaying gender as an issue.

\section{CONCLUSION}

Women on a corporate board are often in the minority. They may have limited access to influential members of an organization to enhance their development in this leadership and decision-making position. Although women on a corporate board may provide a competitive advantage to board decisionmaking, in this study, we add to the body of knowledge related to gender bias the ethical concern that women in leadership positions experience disruptive board dynamics and lowered women's self-esteem. The women can manage gender bias through their empowerment and leadership behaviors to thwart the bias they encounter while executing their roles on a corporate board. Despite the type of bias, women in leadership positions can use the strategies to cope with gender bias checklist to transform themselves which may change men's perceptions of women in the governance structures of society. 


\section{REFERENCES}

Atkinson, S. (2013). Beyond components of wellbeing: The effects of relational and situated assemblage. Topoi, 32, 137-144. doi:10.1007/s11245-013-9164-0

Berdahl, J. L. (2007). Harassment based on sex: Protecting social status in the context of gender hierarchy. Academy of Management Review, 32, 641-658. doi:10.5465/AMR.2007.24351879

Bierema, L. L. (2016). Women's leadership troubling notions of the "ideal" (male) leader. Advances in Developing Human Resources, 18, 119-136. doi:10.1177/1523422316641398

Bruce, A. N., Battista, A., Plankey, M. W., Johnson, L. B., \& Marshall, M. B. (2015). Perceptions of gender-based discrimination during surgical training and practice. Medical Education Online, 20, 1-8. doi:10.3402/meo.v20.25923

Buse, K., Bernstein, R. S., \& Bilimoria, D. (2016). The influence of board diversity, board diversity policies and practices, and board inclusion behaviors on nonprofit governance practices. Journal of Business Ethics, 133, 179-191. doi:10.1007/s10551-014-2352-z

Carr, P. L., Gunn, C. M., Kaplan, S. A., Raj, A., \& Freund, K. M. (2015). Inadequate progress for women in academic medicine: Findings from the National Faculty Study. Journal of Women's Health, 24, 190-199. doi:10.1089/jwh.2014.4848

Cattaneo, L. B., \& Goodman, L. A. (2015). What is empowerment anyway? A model for domestic violence practice, research, and evaluation. Psychology of Violence, 5, 84-94. doi: $10.1037 / \mathrm{a} 0035137$

Cheung, H. K., Lindsey, A., King, E., \& Hebl, M. R. (2016). Beyond sex: Exploring the effects of femininity and masculinity on women's use of influence tactics. Gender in Management: An International Journal, 31, 43-60. doi:10.1108/GM-12-2014-0107

Clerkin, C., \& Ruderman, M. (2018). Developing leaders to tackle "our" problem. Industrial and Organizational Psychology, 11, 341-345. doi:10.1017/iop.2018.28

Cook, A., \& Glass, C. (2014). Women and top leadership positions: Towards an institutional analysis. Gender, Work \& Organization, 21, 91-103. doi:10.1111/gwao.12018

Crawford, W. S., Shanine, K. K., Whitman, M. V., \& Kacmar, K. M. (2016). Examining the impostor phenomenon and work-family conflict. Journal of Managerial Psychology, 31, 375-390. doi:10.1108/JMP-12-2013-0409

Deloitte. (2015). Women in the boardroom: A global perspective. Retrieved from https://www2.deloitte.com/global/en/pages/risk/articles/women-in-the-boardroom-a-globalperspective.html

Derks, B., Van Laar, C., \& Ellemers, N. (2016). The queen bee phenomenon: Why women in leadership positions distance themselves from junior women. Leadership Quarterly, 27, 456-469. doi:10.1016/j.leaqua.2015.12.007

Eagly, A. H., \& Karau, S. J. (2002). Role congruity theory of prejudice toward female leaders. Psychological Review, 109, 573-598. doi:10.1037/0033-295X.109.3.573

EY (2011). The corporate sponsor as hero: Advancing women into leadership roles. Retrieved from http://www.ey.com/Publication/vwLUAssets/EY-The-corporate-sponsor-as-hero/\$FILE/EY-Thecorporate-sponsor-as-hero.pdf

EY (2013). Time for change: Recruiting for Europe's boardroom. Retrieved from http://www.ey.com/Publication/vwLUAssets/EY-Audit-Committee-Time-for-change-Recruitingfor-Europes-boardrooms/\$FILE/EY-Time-for-change-Recruiting-for-Europes-boardrooms.pdf

Fernando, M., \& Chowdhury, R. (2016). Cultivation of virtuousness and self-actualization in the workplace. In A. J. G. Sison, G. R. Beabout, \& I. Ferrero (Eds.), The handbook of virtue ethics in business and management (pp. 1-13). New York, NY: Springer.

Fiksel, J., Polyviou, M., Croxton, K. L., \& Pettit, T. J. (2015). From risk to resilience: Learning to deal with disruption. MIT Sloan Management Review, 56, 79-86. Retrieved from https://sloanreview.mit.edu/article/from-risk-to-resilience-learning-to-deal-with-disruption/

Goffman, E. (1959). The presentation of self in everyday life. New York, NY: Doubleday. 
Groysberg, B., \& Bell, D. (2013, June). Dysfunction in the boardroom. Harvard Business Review, 91, 8895. Retrieved from http://www.hbr.org/

Guba, E. G., \& Lincoln, Y. S. (1983). Epistemological and methodological bases of naturalistic inquiry. Evaluation Models, 311-333. doi:10.1007/978-94-009-6669-7_18

Hays, D. G., Wood, C., Dahl, H., \& Kirk-Jenkins, A. (2016). Methodological rigor in Journal of Counseling \& Development qualitative research articles: A 15-year review. Journal of Counseling \& Development, 94, 172-183. doi:10.1002/jcad.12074

Heilman, M. E. (2012). Gender stereotypes and workplace bias. Research in Organizational Behavior, 32, 113-135. doi:10.1016/j.riob.2012.11.003

Hill, C., Miller, K., Benson, K., \& Handley, G. (2016). Barriers and bias: The status of women in leadership. Washington, DC: American Association of University Women (AAUW).

Holck, L., Muhr, S. L., \& Villesèche, F. (2016). Identity, diversity, and diversity management: On theoretical connections, assumptions and implications for practice. Equality, Diversity and Inclusion: An International Journal, 35, 48-64. doi:10.1108/EDI-08-2014-0061

Jahan, S. (2016). Human development report 2016: Human development for everyone. New York, NY: United Nations Development Programme (UNDP).

Kakabadse, N. K., Figueira, C., Nicolopoulou, K., Hong Yang, J., Kakabadse, A. P., \& Özbilgin, M. F. (2015). Gender diversity and board performance: Women's experiences and perspectives. Human Resource Management, 54, 265-281. doi:10.1002/hrm.21694

Kouzes, J. M., \& Posner, B. Z. (2007). The leadership challenge. San Francisco, CA: John Wiley \& Sons.

Kulik, C. T., \& Metz, I. (2015). Women at the top: Will more women in senior roles impact organizational outcomes? In C. T. Kulik \& I. Metz (Eds.), Oxford handbooks online (pp. 1-55). New York, NY: OHO.

LaPierre, T. A., Hill, S. A., \& Jones, E. V. M. (2016). Women in medicine. In M. L. Connerley \& J. Wu (Eds.), International handbooks of quality-of-life (pp. 263-282). Dordrecht, Netherlands: Springer.

Law, S. A. (1984). Rethinking sex and the constitution. University of Pennsylvania Law School, 132, 9551040. Retrieved from https://scholarship.law.upenn.edu/penn_law_review/vol132/iss5/8/

Lemoine, G. J., Aggarwal, I., \& Steed, L. B. (2016). When women emerge as leaders: Effects of extraversion and gender composition in groups. Leadership Quarterly, 27, 470-486. doi:10.1016/j.leaqua.2015.12.008

Maxwell, J. C. (2007). The 21 irrefutable laws of leadership. Nashville, TN: Thomas Nelson.

Maxwell, J. C. (2011). The 5 levels of leadership. New York, NY: Center Street.

Mayes, R. D., Dollarhide, C. T., Marshall, B., \& Rae, A. (2016). Affective and developmental transitions: Qualitative themes in multicultural counseling journals. International Journal of Information and Learning Technology, 33, 2-16. doi:10.1108/IJILT-10-2015-0031

McGee Bailey, S. (1993). The current status of gender equity research in American Schools. Journal of Educational Psychologist, 28, 321-339. doi:10.1207/s15326985ep2804_3

Mensi-Klarbach, H. (2014). Gender in top management research: Towards a comprehensive research framework. Management Research Review, 37, 538-552. doi:10.1108/MRR-03-2013-0066

Neall, A. M., \& Tuckey, M. R. (2014). A methodological review of research on the antecedents and consequences of workplace harassment. Journal of Occupational and Organizational Psychology, 87, 225-257. doi:10.1111/joop.12059

Patel, G., \& Buiting, S. (2013). Gender differences in leadership styles and the impact within corporate boards. Retrieved from http://www.cpahq.org/cpahq/cpadocs/Genderdiffe.pdf

Patton, M. Q. (2015). Qualitative research and evaluation methods (4th ed.). Thousand Oaks, CA: Sage.

Rhode, D., \& Packel, A. K. (2014). Diversity on corporate boards: How much difference does difference make? Delaware Journal of Corporate Law, 39, 377-426. doi:10.2139/ssrn.1685615

Roberts, S. (2018, April 7). Exploring how women on corporate boards cope with gender bias (Ph.D. Dissertation). Retrieved from ProQuest Dissertations \& Theses Global. (UMI 10747062).

Saldana, J. (2012). The coding manual for qualitative researchers (2nd ed.). Thousand Oaks, CA: Sage. 
Schneider, B., Ehrhart, M. G., \& Macey, W. H. (2013). Organizational climate and culture. Annual Review of Psychology, 64, 361-388. doi:10.1146/annurev-psych-113011-143809

Seierstad, C., Warner-Søderholm, G., Torchia, M., \& Huse, M. (2017). Increasing the number of women on boards: The role of actors and processes. Journal of Business Ethics, 141, 289-315. doi:10.1007/s10551-015-2715-0

Smith, B. (2014). How might information bolster anti-discrimination laws to promote more familyfriendly workplaces? Journal of Industrial Relations, 65, 547-565. doi:10.1177/0022185614540128

Statistics Canada. (2016, April 19). Statistics Canada: Latest indicators. Retrieved from http://www.statcan.gc.ca/start-debut-eng.html

Statistics Canada. (2016, September 15). Education in Canada: Attainment, field of study and location of study. Retrieved from http://www12.statcan.gc.ca/nhs-enm/2011/as-sa/99-012-x/99-012x2011001-eng.pdf

Status of Women Canada. (2016, May 3). Status of Women Canada: Women on boards. Retrieved from http://www.swc-cfc.gc.ca/initiatives/wldp/wb-ca/wob-fca-eng.html

Tajfel, H., \& Turner, J. C. (1979). An integrative theory of intergroup conflict. In W. G. Austin \& S. Worchel (Eds.), The social psychology of intergroup relations (pp. 33-47). Monterey, CA: Brooks/Cole.

United Nations Development Programme. (2016). Gender Inequality Index (GII). Retrieved from $\mathrm{http} / /$ hdr.undp.org/en/content/gender-inequality-index-gii

Vinkenburg, C. J., Jansen, P. G., Dries, N., \& Pepermans, R. (2014). Arena: A critical conceptual framework of top management selection. Group \& Organization Management, 39, 33-68. doi:10.1177/1059601113492846

Yin, R. K. (2011). Case study research: Design and methods (5th ed.). New York, NY: The Guilford Press.

Zhu, D. H., Wei, S., \& Hillman, A. J. (2014). Recategorization into the in-group: The appointment of demographically different new directors and their subsequent positions on corporate boards. Administrative Science Quarterly, 59, 240-270. doi:10.1177/0001839214530951 